\title{
Thorium compounds with bonds to Sulfur or Selenium: Synthesis, Structure, and Thermolysis
}

\author{
David Rehe, Anna Y. Kornienko, Thomas J. Emge and John G. Brennan* \\ Department of Chemistry and Chemical Biology, Rutgers, the State University of New Jersey, \\ 610 Taylor Road, Piscataway NJ 08854-8087, United States \\ *Email: bren@rci.rutgers.edu
}

\section{Supporting Information (SI)}

\section{Table of contents}

1. X-ray powder diffraction profiles and the profiles of calculated diffraction patterns for $(\mathrm{py})_{4} \mathrm{Th}(\mathrm{SPh})_{4}(1),(\mathrm{py})_{3} \mathrm{Th}(\mathrm{SePh})_{4} \cdot 0.5 \mathrm{py}(2),(\mathrm{py})_{3} \mathrm{Th}\left(\mathrm{SC}_{6} \mathrm{~F}_{5}\right)_{4}(3)$ and $(\mathrm{py})_{4} \mathrm{Th}\left(\mathrm{SeC}_{6} \mathrm{~F}_{5}\right)_{4} \cdot 1.5$ py (4)

2. ${ }^{1} \mathrm{H}$ NMR data for all four compounds and ${ }^{19} \mathrm{~F}$ NMR data for compounds 3 and 4 .

3. PXRD profiles of thermolysis products at $650^{\circ} \mathrm{C}$ and $850^{\circ} \mathrm{C}$.

4. Unit cell packing diagrams for $\mathbf{1}, \mathbf{2}, 3$ and 4 . 
1. X-ray powder diffraction profiles and the profiles of calculated diffraction patterns for $(\mathrm{py})_{4} \mathrm{Th}(\mathrm{SPh})_{4}(1),(\mathrm{py})_{3} \mathrm{Th}(\mathrm{SePh})_{4} \cdot 0.5 \mathrm{py}(2),(\mathrm{py})_{3} \mathrm{Th}\left(\mathrm{SC}_{6} \mathrm{~F}_{5}\right)_{4}(3)$ and $(\mathrm{py})_{4} \operatorname{Th}\left(\mathrm{SeC}_{6} \mathrm{~F}_{5}\right)_{4} \cdot 1.5 \mathrm{py}(4)$

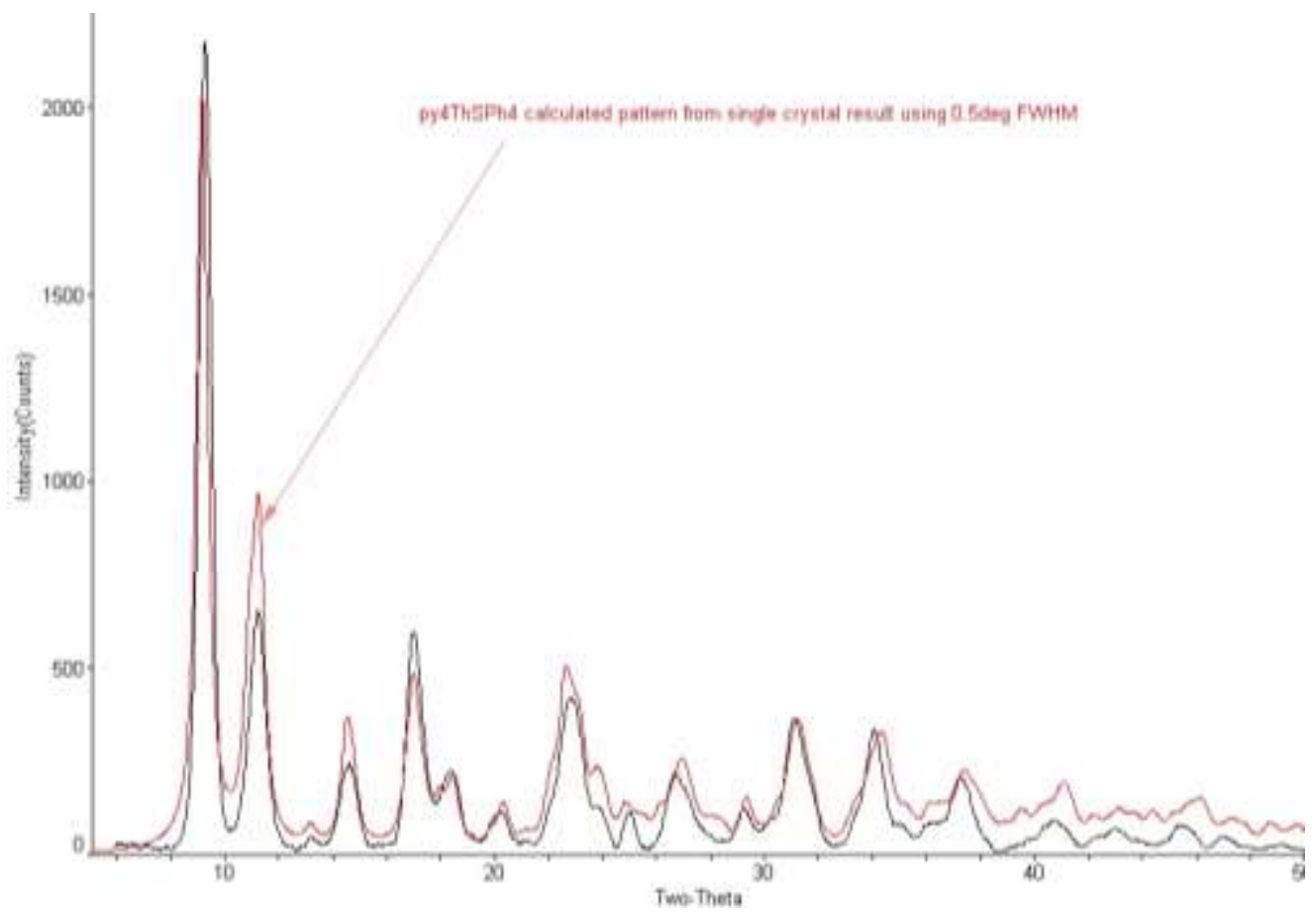

Figure $S 1$.

PXRD and calculated pattern from single crystal (in red) for $(\mathbf{p y})_{4} \mathbf{T h}(\mathbf{S P h})_{4}(\mathbf{1})$.

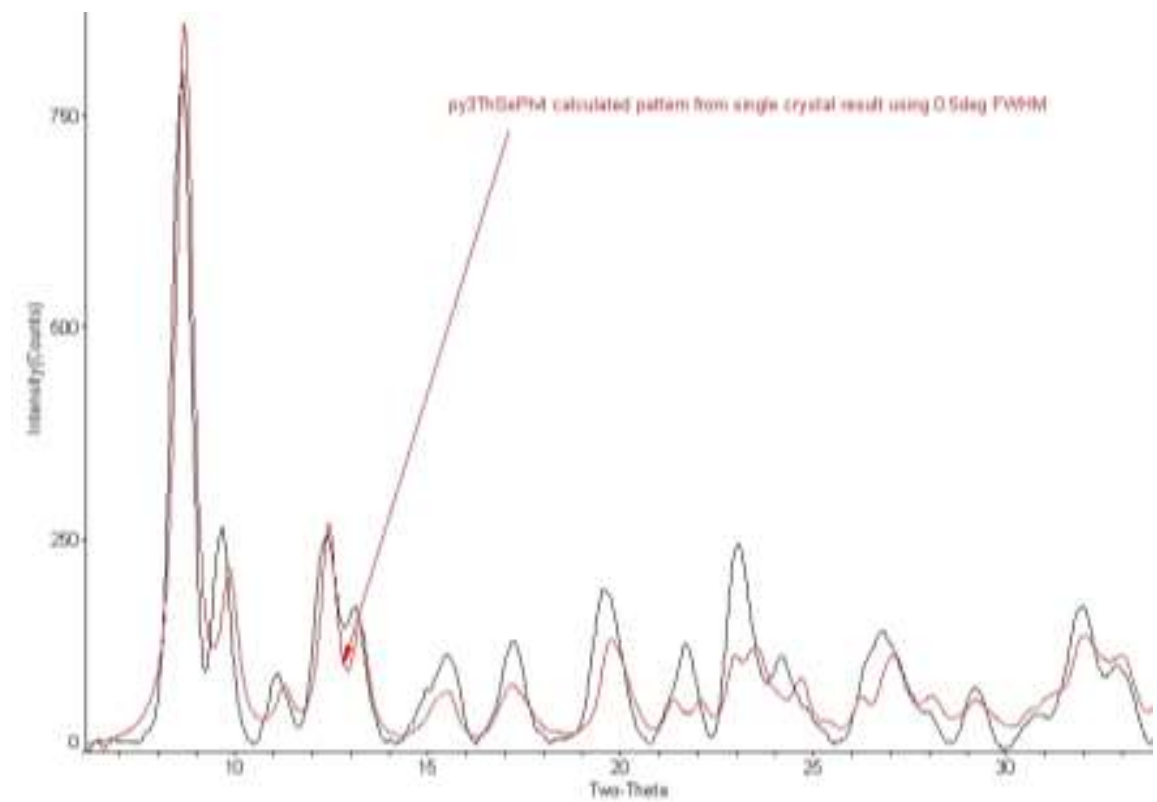

Figure $S 2$.

PXRD and calculated pattern from single crystal (in red) for $(\mathbf{p y})_{3} \mathbf{T h}(\mathbf{S e P h})_{4} \cdot \mathbf{0 . 5 p y}(2)$. 


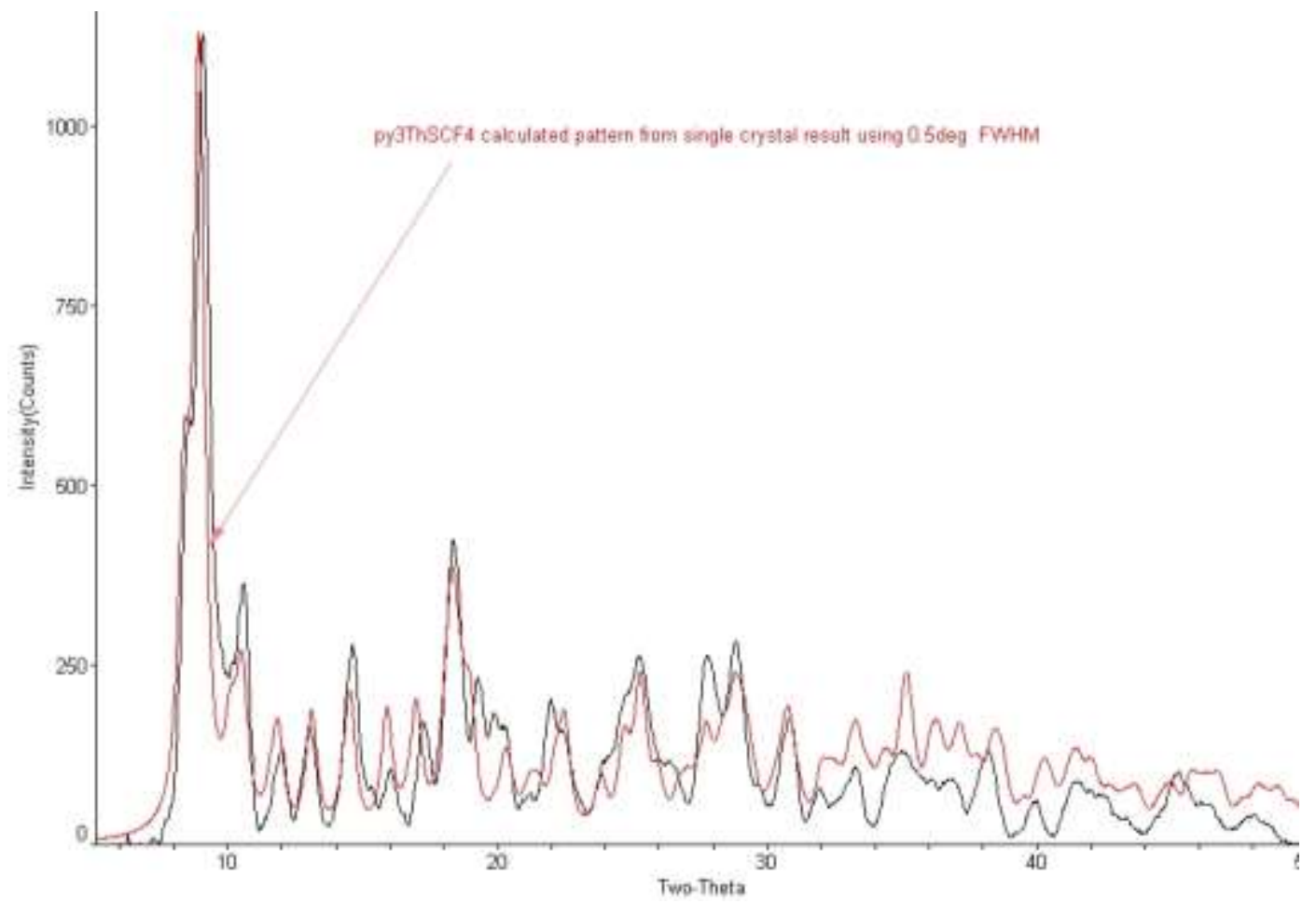

Figure S3.

PXRD and calculated pattern from single crystal (in red) for $(\mathbf{p y})_{3} \mathbf{T h}\left(\mathbf{S C}_{6} \mathbf{F}_{5}\right)_{4}(\mathbf{3})$.

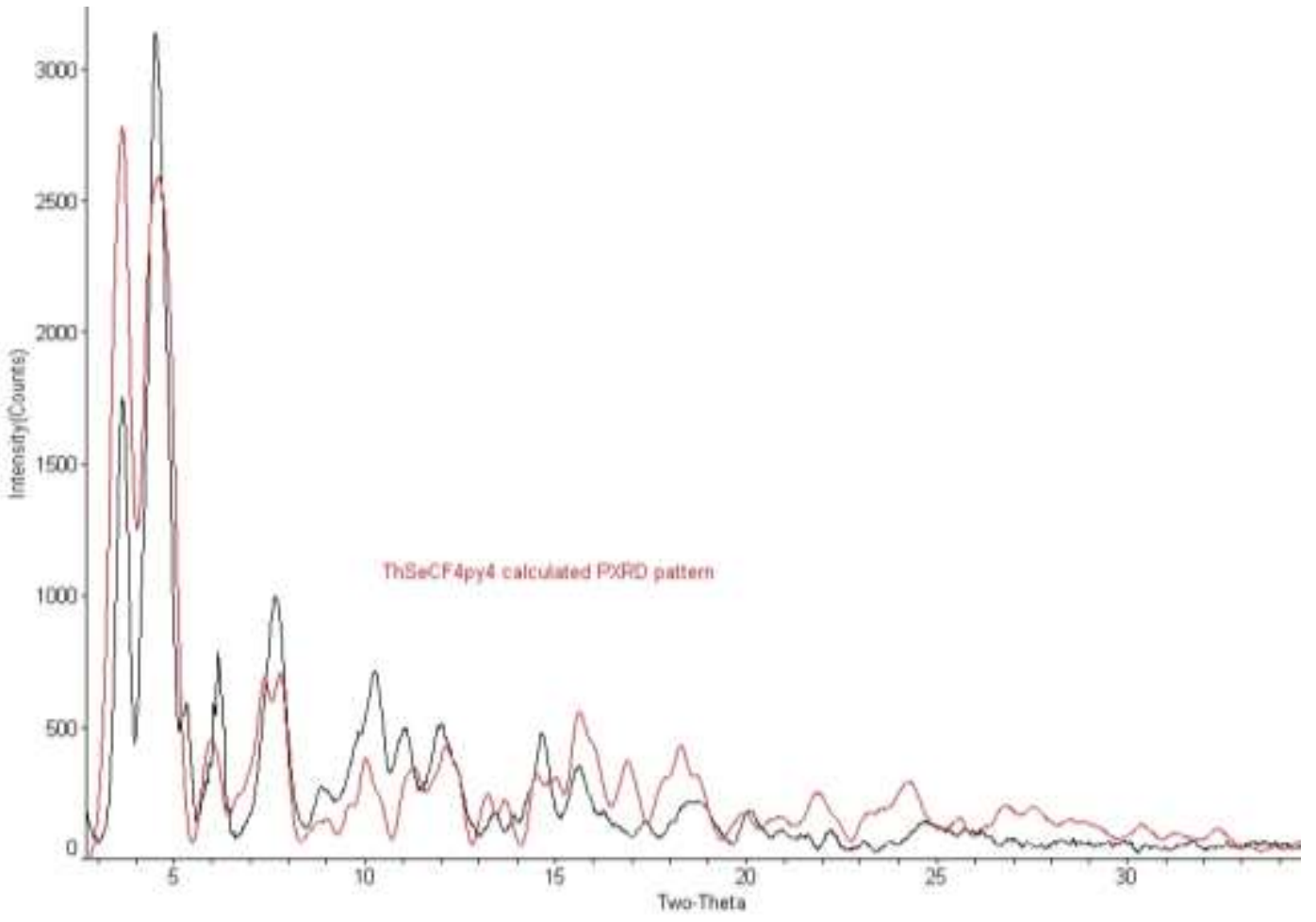

Figure S4.

PXRD and calculated pattern from single crystal (in red) for $(\mathbf{p y})_{4} \operatorname{Th}\left(\mathrm{SeC}_{6} \mathbf{F}_{5}\right)_{4} \cdot 1.5 \mathrm{py}$ (4). 
2. ${ }^{1}$ H NMR data for all four compounds and ${ }^{19}$ F NMR data for compounds 3 and 4 .

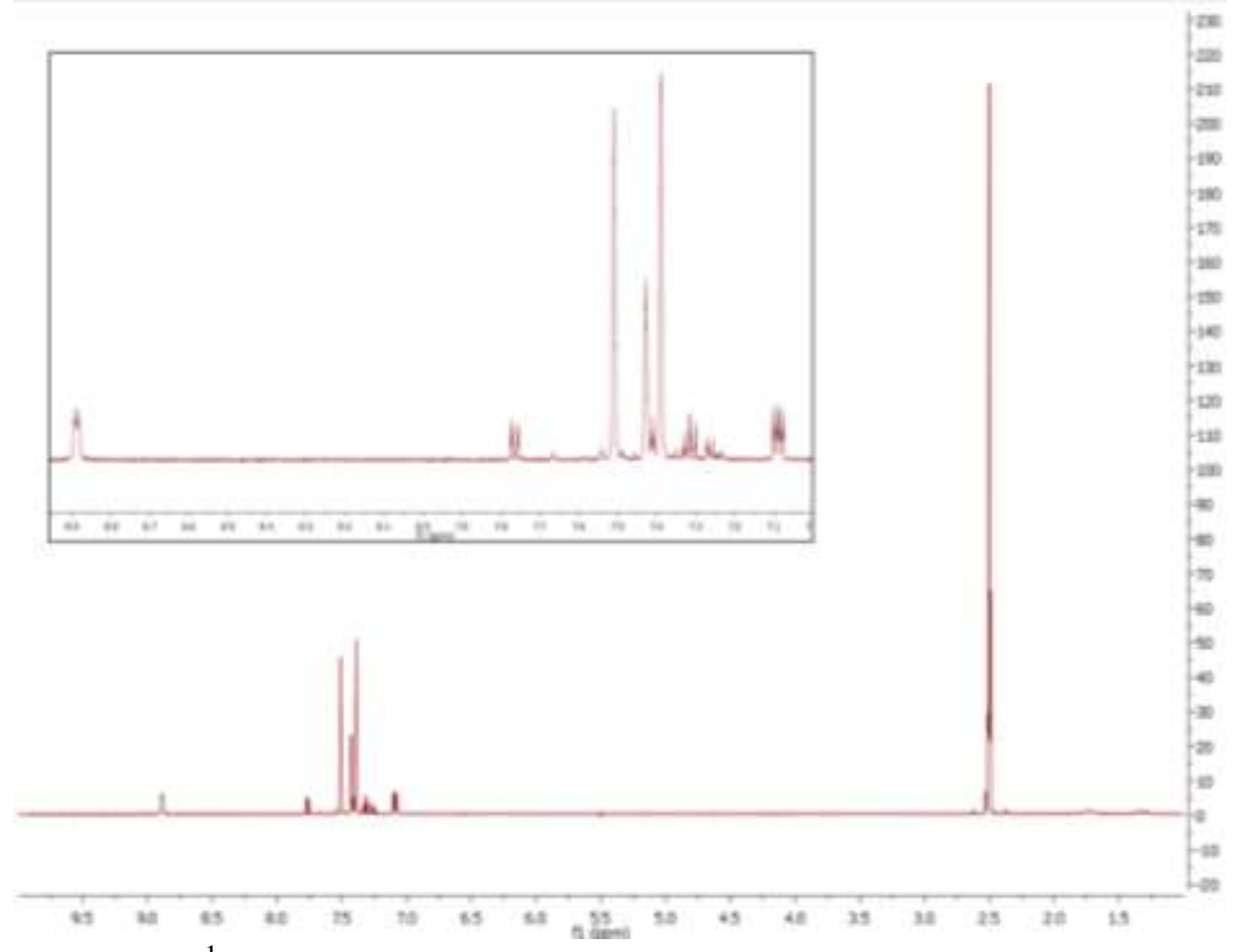

Figure $S 5 .{ }^{1} \mathrm{H}$ NMR (toluene $-d_{8}$ ) spectrum of $(\mathbf{p y})_{4} \mathbf{T h}(\mathbf{S P h})_{4}(\mathbf{1})$.

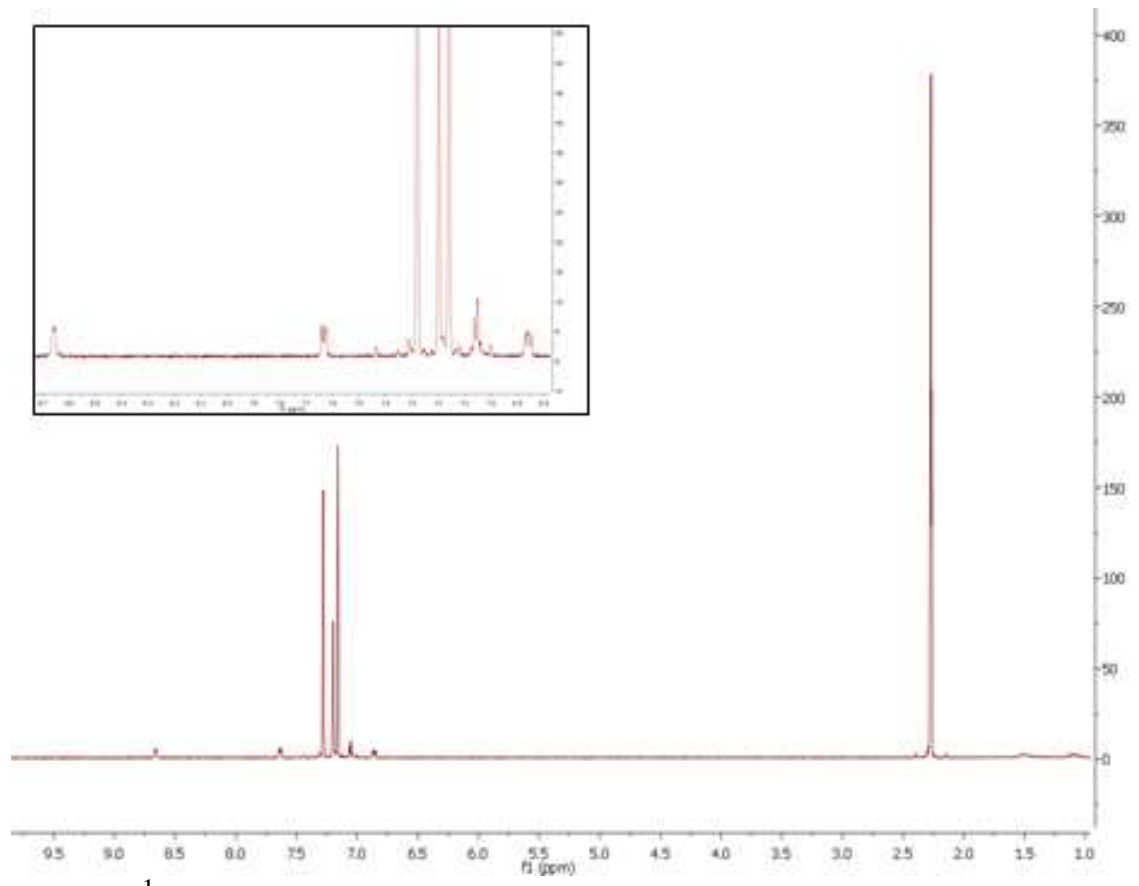

Figure $S 6 .{ }^{1} \mathrm{H}$ NMR (toluene $-d_{8}$ ) spectrum of $(\mathbf{p y})_{3} \mathbf{T h}(\mathbf{S e P h})_{4} \cdot \mathbf{0 . 5 p y}(2)$. 

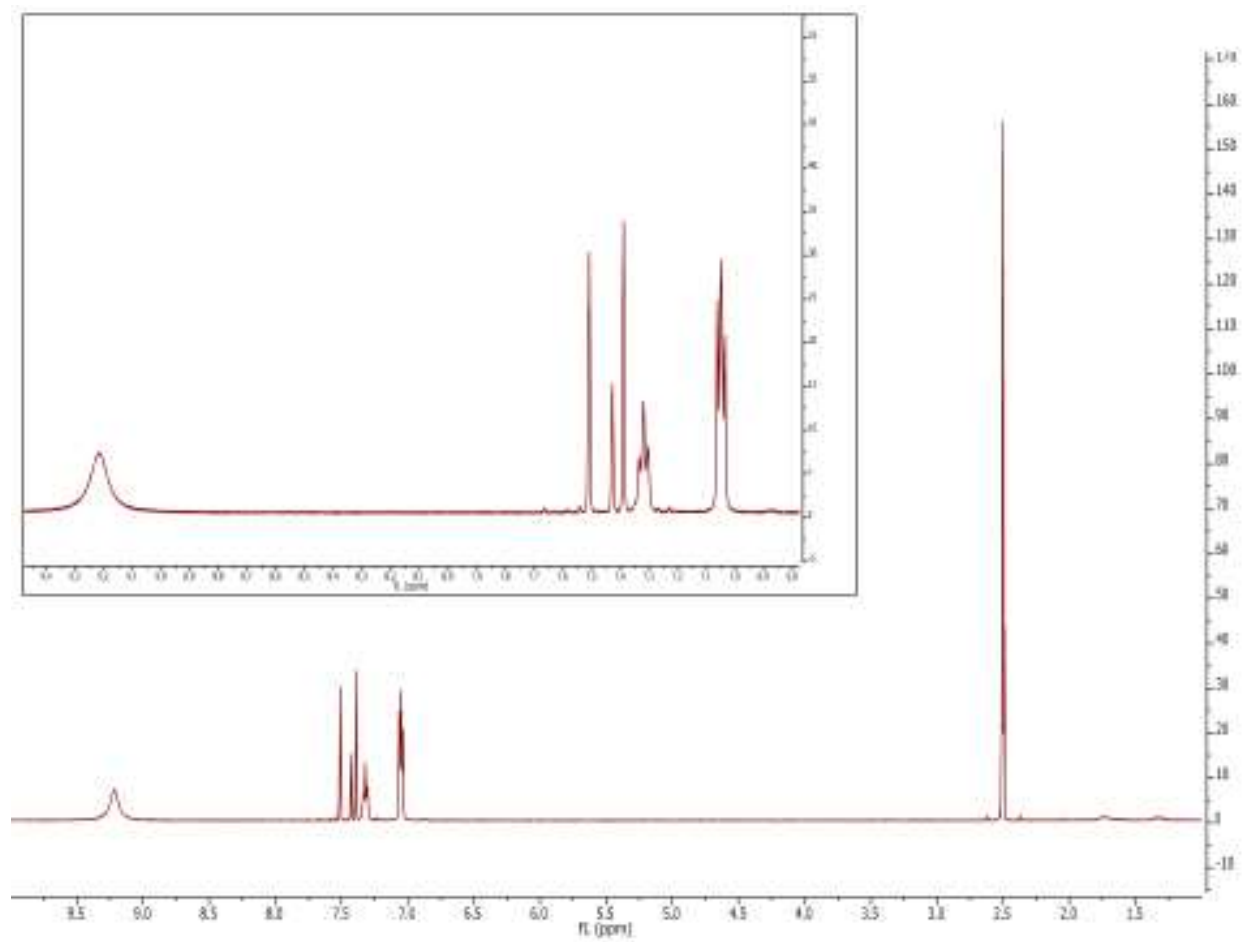

Figure $S 7 .{ }^{1} \mathrm{H}$ NMR (toluene $\left.-d_{8}\right)$ spectrum of $(\mathbf{p y})_{\mathbf{3}} \mathbf{T h}\left(\mathbf{S C}_{6} \mathbf{F}_{5}\right)_{\mathbf{4}}(\mathbf{3})$.

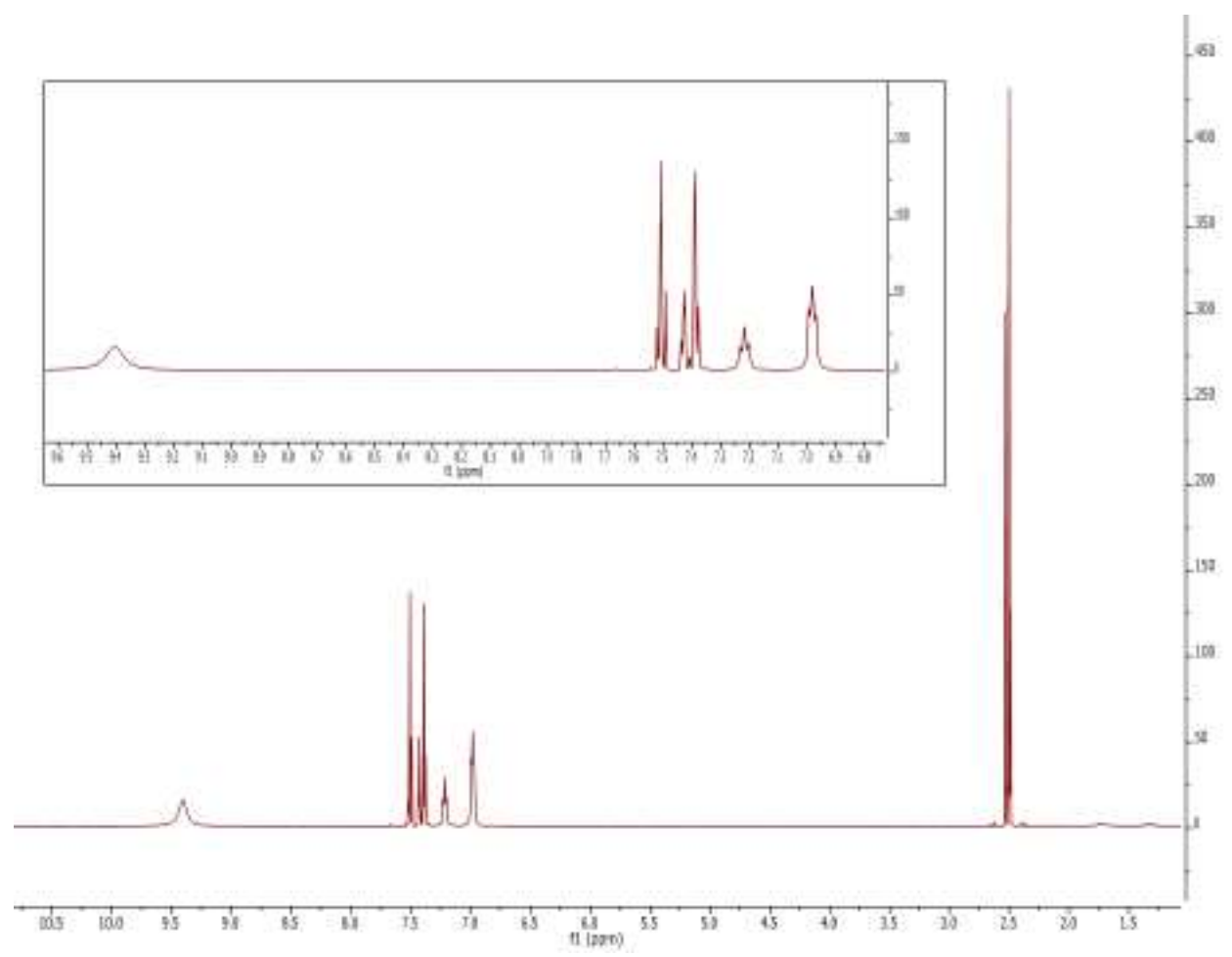

Figure $S 8 .{ }^{1} \mathrm{H}$ NMR (toluene $\left.-d_{8}\right)$ spectrum of $(\mathbf{p y})_{\mathbf{4}} \mathbf{T h}\left(\mathrm{SeC}_{6} \mathbf{F}_{5}\right)_{\mathbf{4}} \cdot \mathbf{1 . 5} \mathbf{p y}$ (4). 


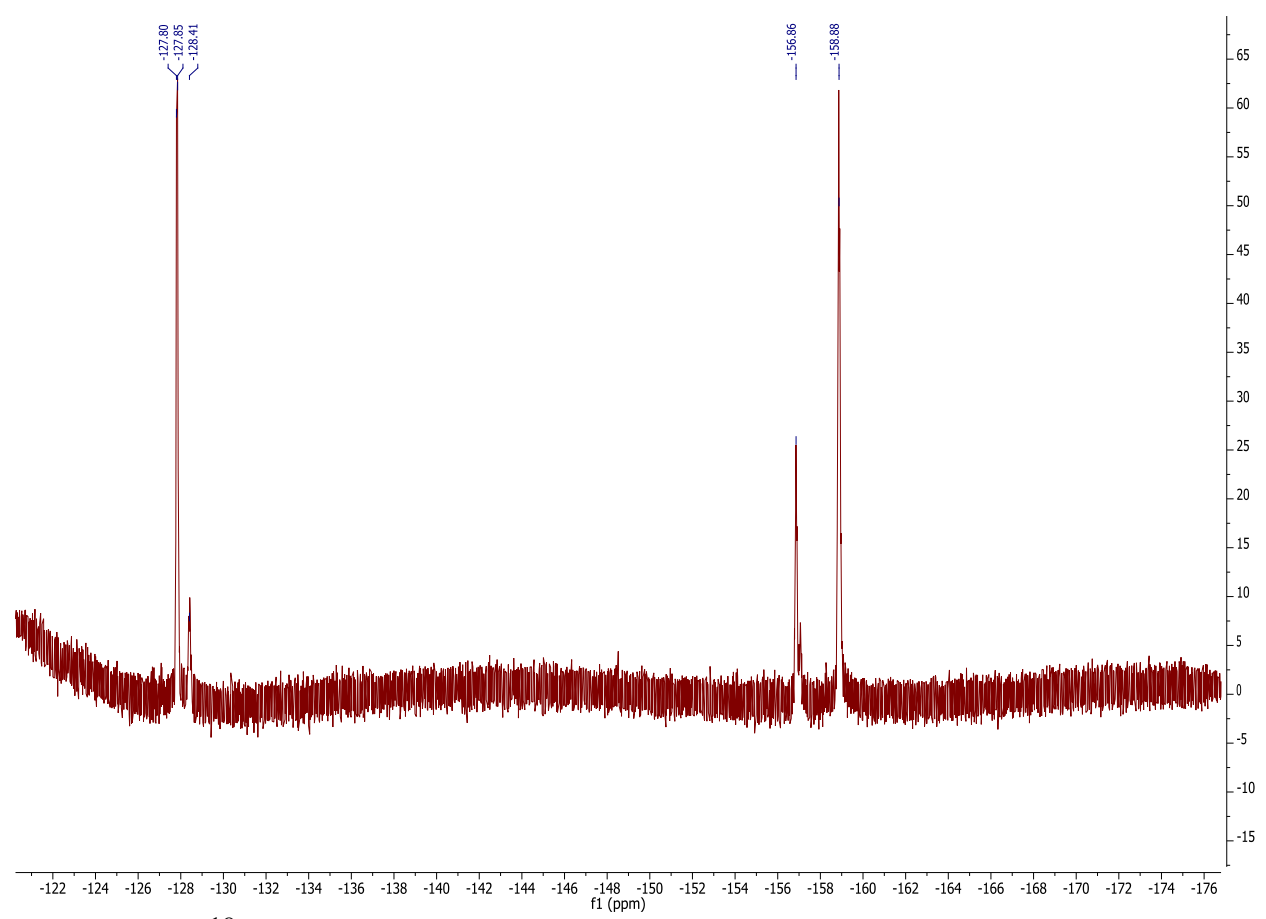

Figure S9. ${ }^{19}$ F NMR (toluene $\left.-d_{8}\right)$ spectrum of $(\mathbf{p y})_{\mathbf{3}} \mathbf{T h}\left(\mathbf{S C}_{\mathbf{6}} \mathbf{F}_{\mathbf{5}}\right)_{\mathbf{4}}(\mathbf{3})$.

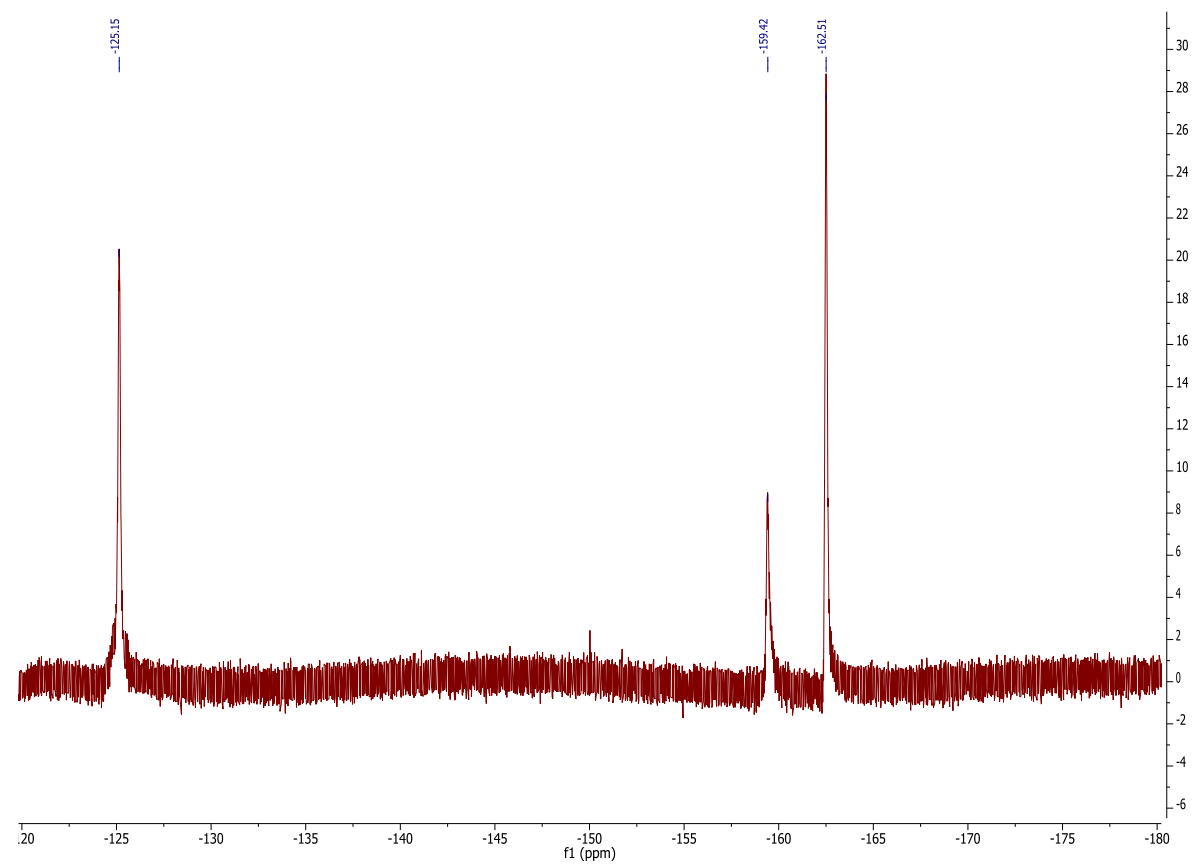

Figure $\boldsymbol{S 1 0} .{ }^{19} \mathrm{~F}$ NMR (toluene $\left.-d_{8}\right)$ spectrum of $(\mathbf{p y})_{4} \mathbf{T h}\left(\mathbf{S e C}_{6} \mathbf{F}_{5}\right)_{4} \cdot 1.5$ py (4). 


\section{PXRD profiles of thermolysis products at $650^{\circ} \mathrm{C}$ and $850^{\circ} \mathrm{C}$.}

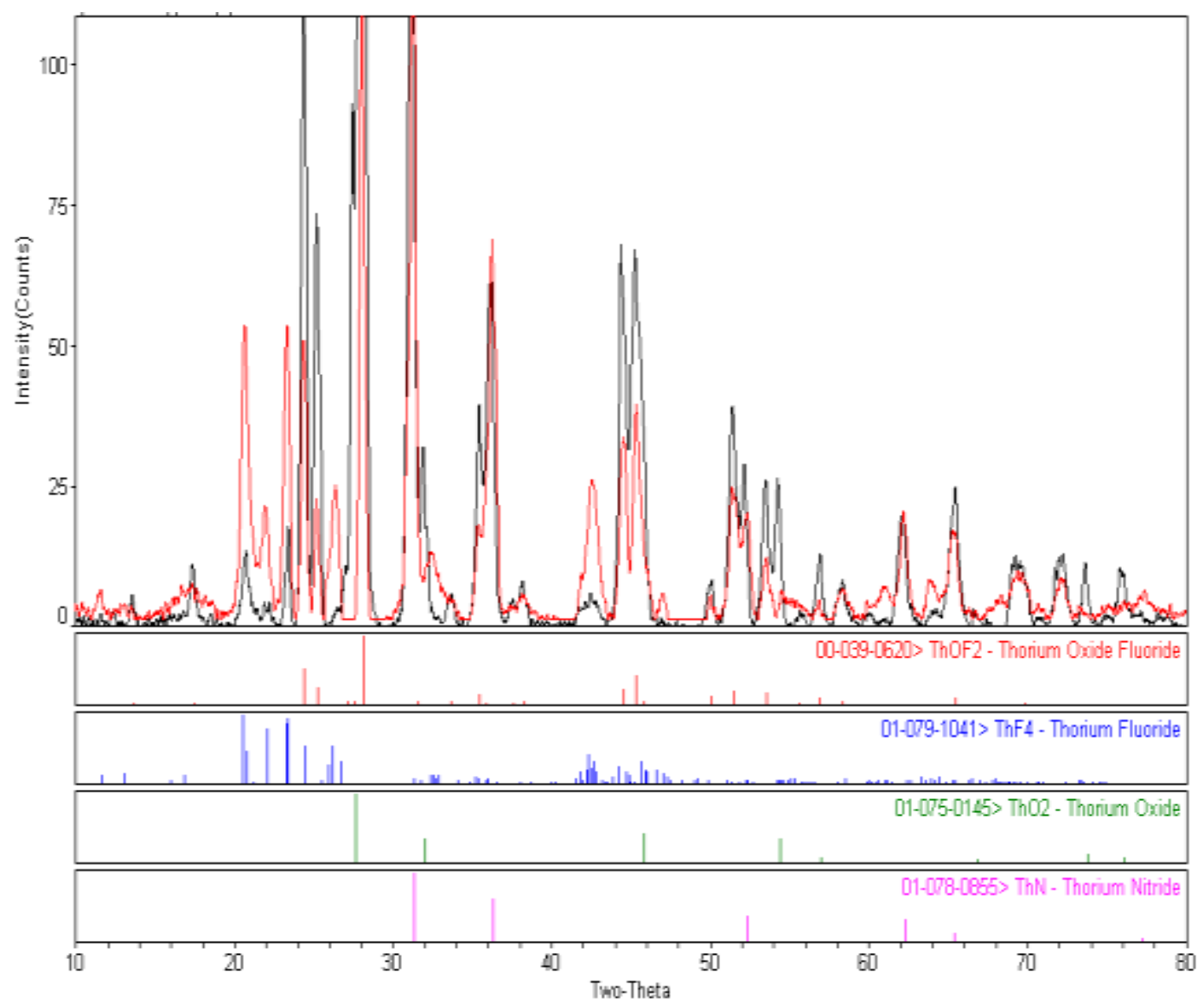

Figure $S 11$. PXRD profiles and confirmed products after thermolysis of $(\mathbf{p y})_{4} \mathbf{T h}\left(\mathbf{S e C}_{6} \mathbf{F}_{5}\right)_{4} \cdot$ 1.5 py (4) at $650^{\circ} \mathrm{C}$. Two samples were collected for analysis, one from the bottom of the thermolysis tube (black profile) and the other from the middle (red profile) part of the same tube. Both samples contained mostly $\mathrm{ThF}_{4}$ and $\mathrm{ThOF}_{2}$, with $\mathrm{ThF}_{4}$ in noticeably greater abundance for the middle part. The existence of $\mathrm{ThO}_{2}$ is based primarily upon one peak at 32 $\operatorname{deg} 2 \theta$. 


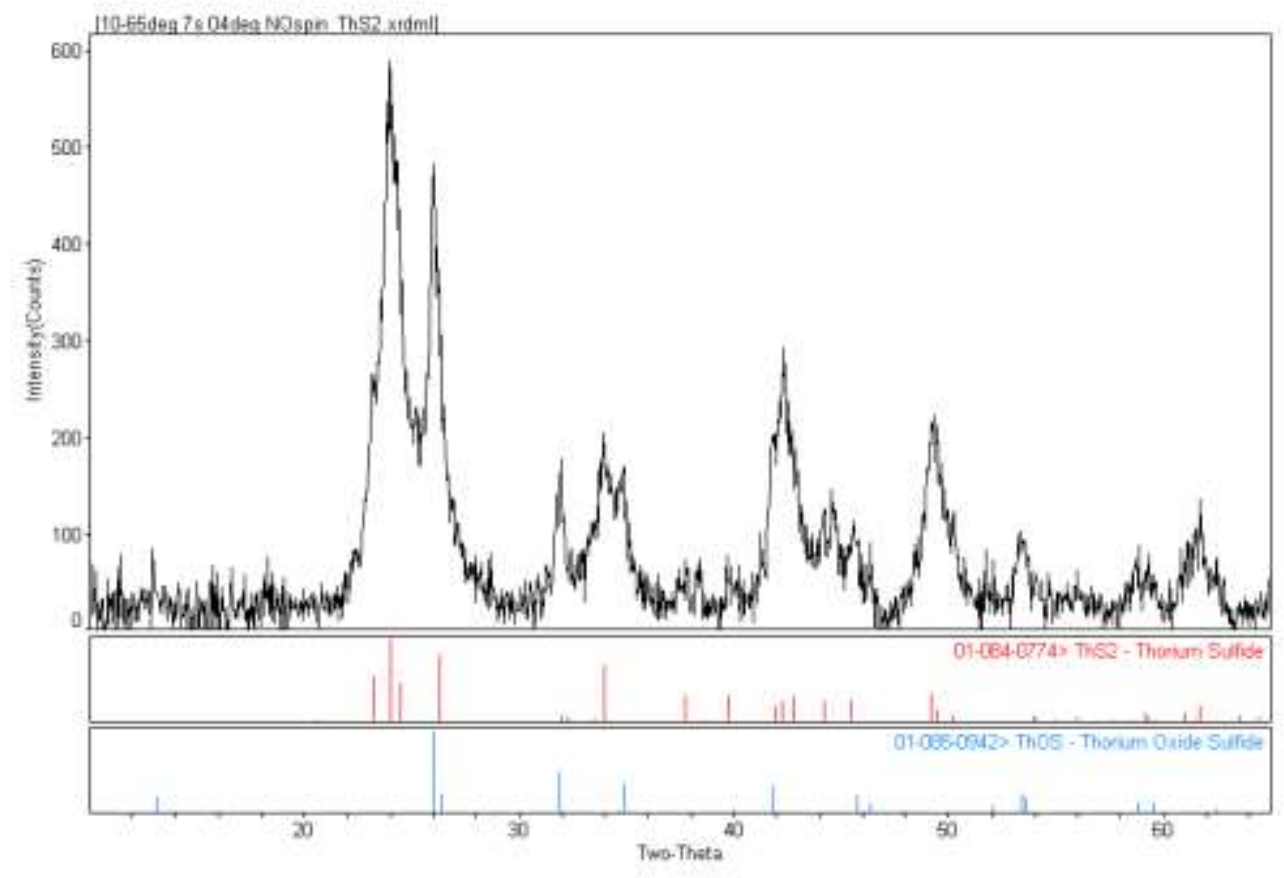

Figure $S 12$. PXRD of the thermolysis products of $(\mathbf{p y})_{4} \mathbf{T h}(\mathbf{S P h})_{4}(\mathbf{1})$ at $850^{\circ} \mathrm{C}$. ThOS present in lesser amount than $\mathrm{ThS}_{2}$, and no other products were detected. 


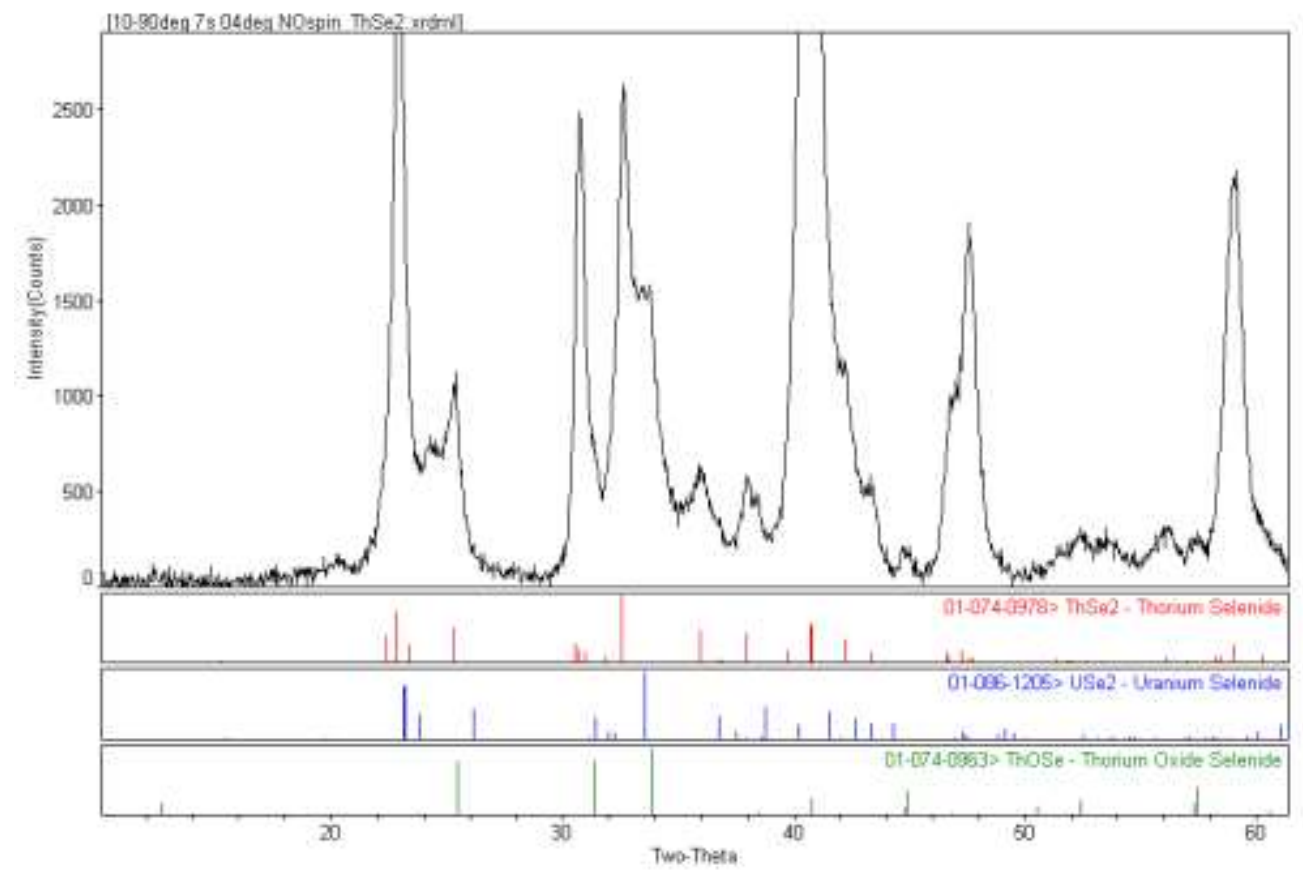

Figure $S 13$. PXRD of the thermolysis products of $(\mathbf{p y})_{3} \mathbf{T h}(\mathbf{S e P h})_{4} \cdot \mathbf{0 . 5 p y}(2)$ at $850^{\circ} \mathrm{C}$. ThOSe present in lesser amount than $\mathrm{ThSe}_{2}$. Another phase for $\mathrm{ThSe}_{2}$ similar to the $\mathrm{USe}_{4}$ orthorhombic phase may also be present. 


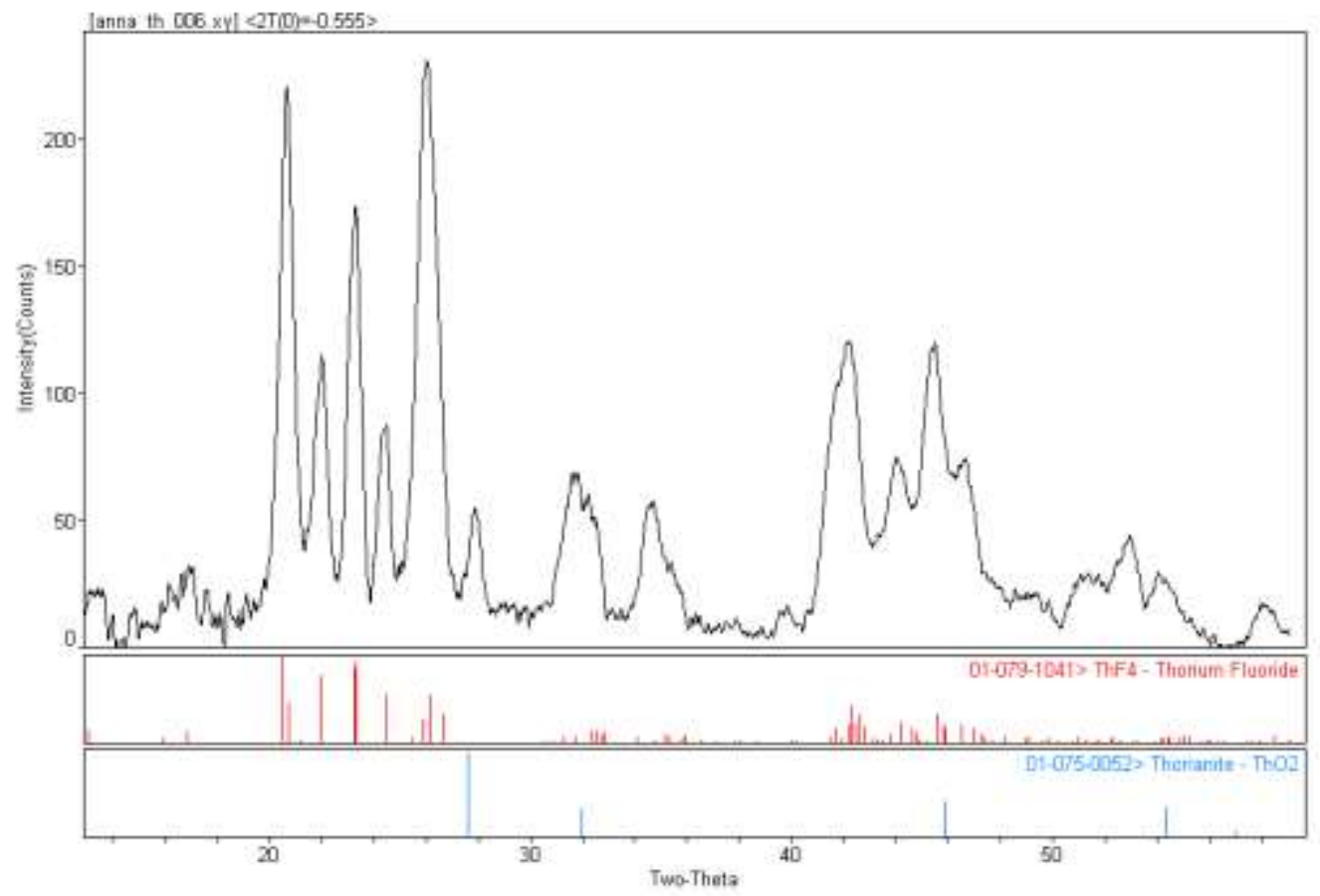

Figure $S 14$. PXRD of the thermolysis products of $(\mathbf{p y})_{3} \mathbf{T h}\left(\mathrm{SC}_{6} \mathbf{F}_{5}\right)_{4}(3)$ and $(\mathbf{p y})_{4} \mathbf{T h}\left(\mathrm{SeC}_{6} \mathbf{F}_{5}\right)_{4} \cdot 1.5$ py (4) at $850^{\circ} \mathrm{C}$ were similar, with that of 4 shown here. $\mathrm{ThO}_{2}$ present in small amount, and $\mathrm{ThOF}_{2}$ and $\mathrm{ThOSe}$ are not present. 
4. Unit cell packing diagrams for $1,2,3$ and 4 .

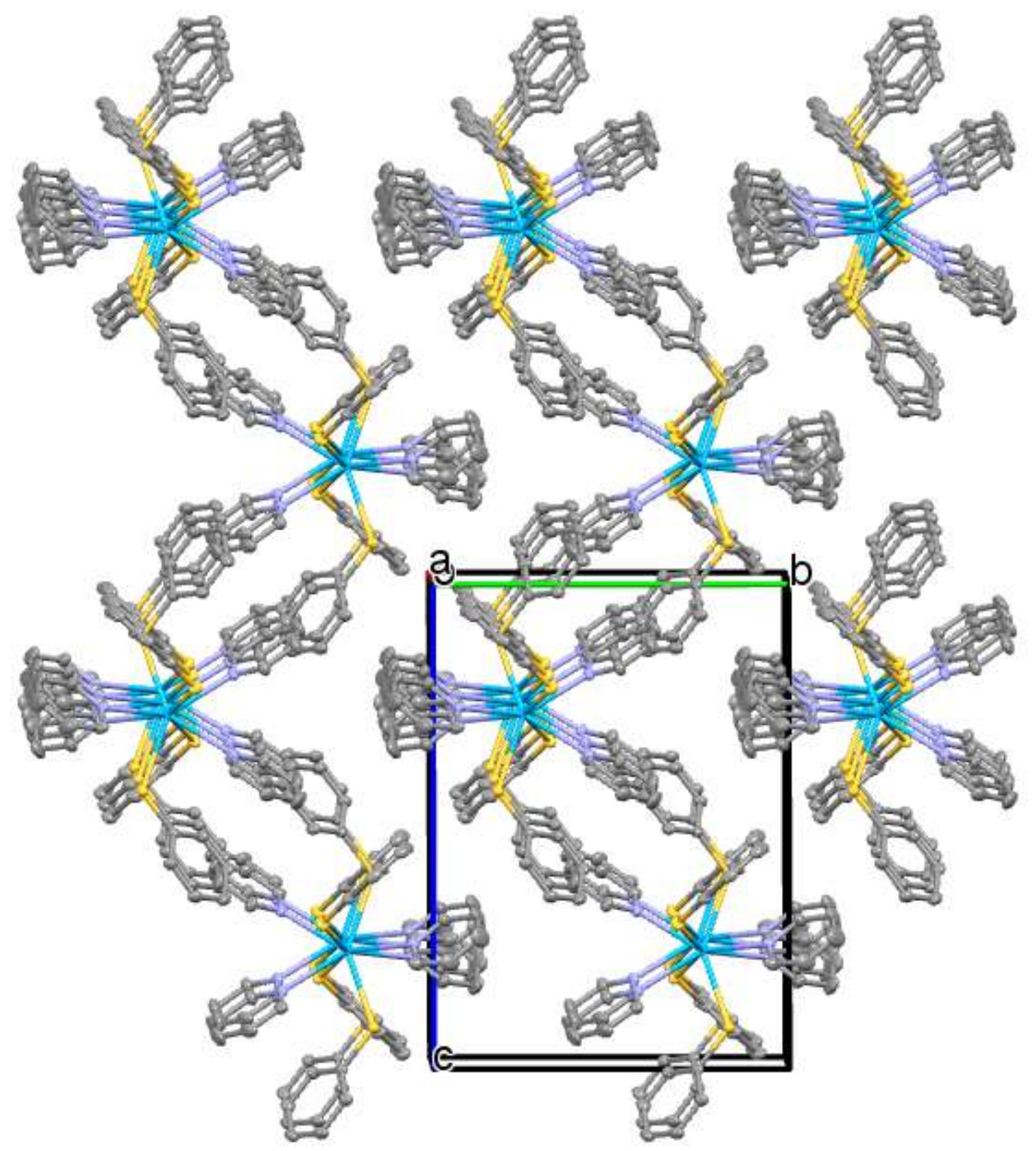

Figure $S 15$. Unit cell packing viewed along the crystallographic a axis for $(\text { py })_{4} \mathbf{T h}(\mathrm{SPh})_{4}(1)$ 


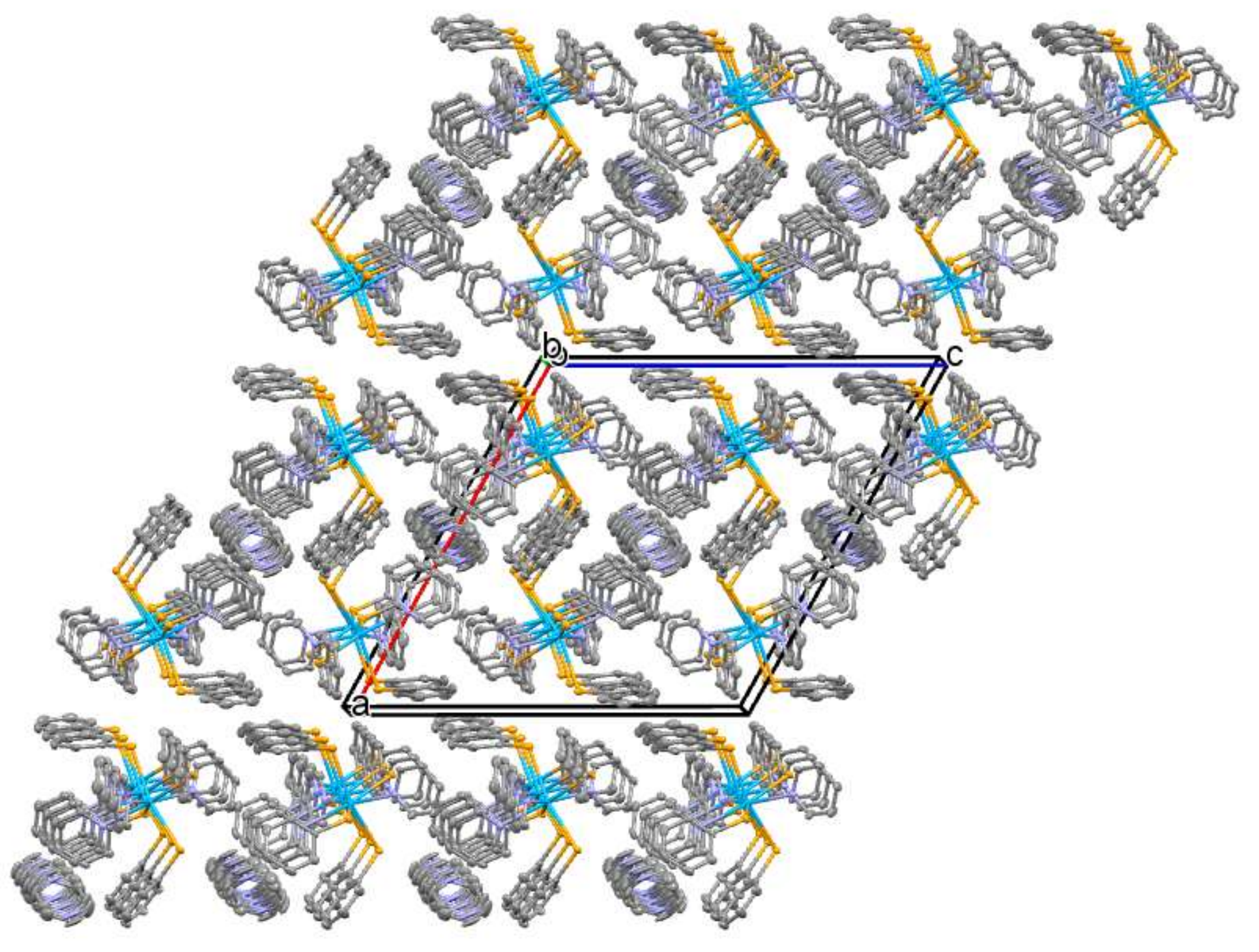

Figure $\boldsymbol{S 1 6}$. Unit cell packing viewed along the crystallographic a axis for $(\mathrm{py})_{3} \mathrm{Th}(\mathrm{SePh})_{4} \cdot 0.5 \mathrm{py}(2)$ 


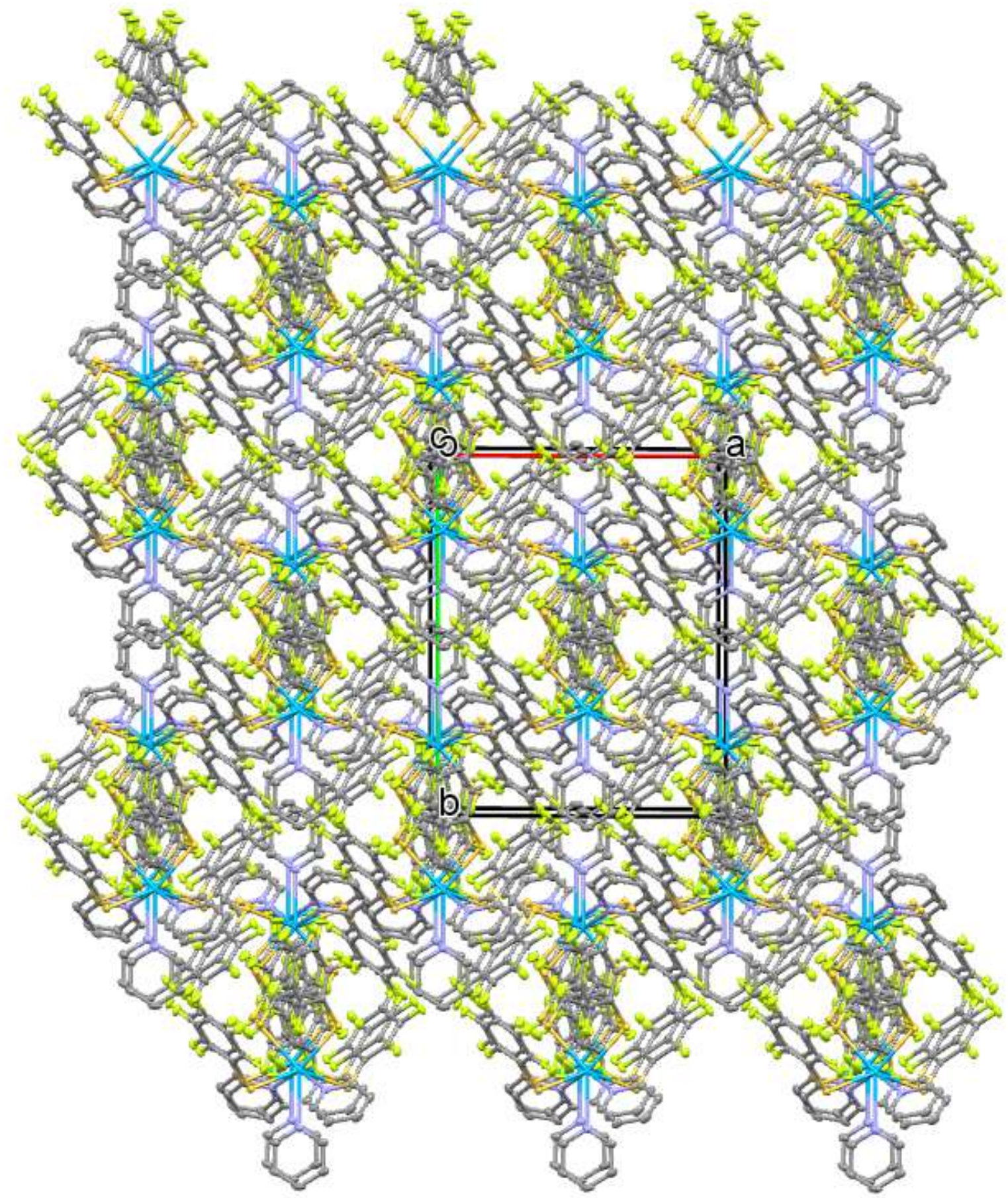

Figure $S$ 17. Unit cell packing viewed along the crystallographic a axis for $(\mathrm{py})_{3} \mathrm{Th}\left(\mathrm{SC}_{6} \mathrm{~F}_{5}\right)_{4}$ (3) 


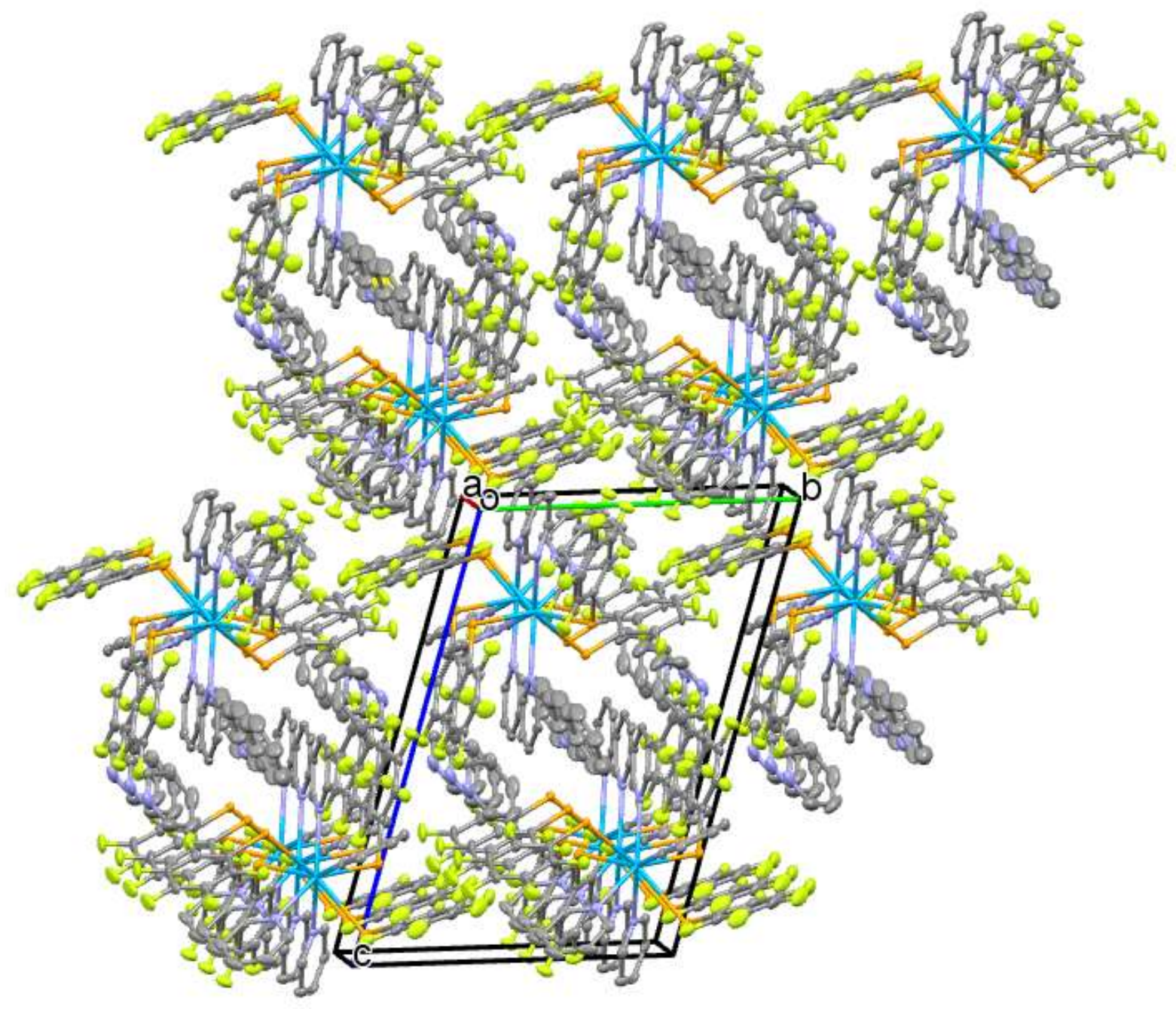

Figure $\boldsymbol{S 1 8}$. Unit cell packing viewed along the crystallographic a axis for $(\mathrm{py})_{4} \mathrm{Th}\left(\mathrm{SeC}_{6} \mathrm{~F}_{5}\right)_{4} \cdot 1.5 \mathrm{py}(4)$ 